\title{
Les défis des crises
}

L'épidémie de COVID-19 qui submerge le monde entier soulève des défis majeurs de santé publique pour la phase d'urgence (avec confinement) et la phase de récupération (avec levée du confinement). À première vue, il y a de nombreuses similitudes entre la crise COVID-19 et un accident nucléaire/radiologique.

Dans le cas de la crise du COVID 19, on peut observer des différences notables dans la gestion de la crise entre les différents pays du monde. L'impact de l'épidémie varie énormément d'un pays à l'autre, sans qu'il soit totalement certain que ces différences de gestion en soient à l'origine. Le retour d'expérience nous le dira plus précisément dans quelques semaines ou mois. On peut également souligner les débats scientifiques, porteurs d'opinions fortes et souvent contradictoires, qui ne permettent pas de clarifier la situation. Ceci relève pleinement du positionnement de l'expert dans le débat, question largement débattue à la suite de l'accident de Fukushima.

En conséquence, la crise liée à la pandémie de COVID-19 est un signe de défi pour nous scientifiques et spécialistes dans tous les domaines de la radioprotection. En France, la préparation à l'accident est un thème de travail porté par les autorités depuis 2005. Mais sommes-nous vraiment prêts pour faire face à un accident nucléaire/radiologique de grande ampleur? Aurons-nous en stock les équipements de base nécessaires aux acteurs principaux de la crise et à la population pour bien gérer la situation, comme par exemple les dosimètres électroniques lors de la phase d'urgence ou les détecteurs et spectromètres de rayonnements lors de la phase post-accidentelle? Avons-nous des processus de décision assez robustes pour faire face aux conséquences radiologiques, sanitaires et sociales importantes pendant la phase d'urgence et en phase post-accidentelle?

Cependant, il existe une différence majeure avec la crise COVID-19 : la préparation à un accident nucléaire ou radiologique est active dans la plupart des pays et fortement basée sur l'expérience gagnée lors de la gestion partagée des accidents nucléaires de Tchernobyl et de Fukushima via de nombreux projets de recherche européens. En fait, la préparation et la réponse aux situations d'urgence nucléaire ou radiologique sont depuis fort longtemps l'objet de recherches et constituent naturellement une ligne éditoriale du journal Radioprotection.

Dans ce numéro, nous publions deux articles sur la préparation à la crise. Le premier article de Croüail et al. est intitulé «Analyse des modalités de retour des populations dans les territoires contaminés à la suite de l'accident de la centrale nucléaire de Fukushima » (Croüail et al., 2020). Cette analyse révèle la complexité de la situation dans un contexte de grandes incertitudes et met aussi en exergue le besoin de décideurs et d'aides à la décision (e.g., experts en radioprotection et experts médicaux) pour prendre en compte et respecter les différents choix faits ou envisagés par les communautés impactées pour lesquelles les questions radiologiques ne sont qu'un des aspects du problème. Le second article de Maître et al. est intitulé «Les processus d'implication des parties prenantes dans la gestion des situations post-accidentelles - quelles leçons pour la préparation?» (Maitre et al., 2020). Cet article synthétise les recommandations résultant de six projets de recherche européens menés sur une période de 6 ans (20132019) et montre l'importance de la préparation, en débutant dès que possible des dialogues avec les parties prenantes dans les domaines potentiellement touchés par l'accident nucléaire.

De plus, Radioprotection a le plaisir de publier actuellement deux numéros spéciaux dédiés à la gestion des crises nucléaires avec des séries d'articles qui présentent les dernières avancées des projets européens CONFIDENCE et ENGAGE. Le projet CONFIDENCE effectue des recherches centrées sur les incertitudes dans les domaines de la gestion de l'urgence et de la réhabilitation à long terme. Ce projet est focalisé sur les phases précoces et de transition de l'urgence, mais considère aussi les décisions de plus long terme prises pendant ces phases avec une attention spécifique sur les aspects sociaux, éthiques et de communication (Raskob et al., 2020). Le projet ENGAGE vise à identifier et faciliter pour les parties prenantes les occasions de s'engager dans la gestion des expositions post-accidentelles aux rayonnements ionisants. Il porte aussi sur le développement de la culture de radioprotection (incluant aussi les expositions médicales et au radon domestique) (Turcanu et Duranova, 2020; Turcanu et al., 2020).

En conclusion, les défis actuels de la gestion de crise portent essentiellement sur la manière dont les différents acteurs de la société (décideurs, parties prenantes et population) peuvent partager l'évaluation des différents risques (conséquences sanitaires des expositions radiologiques, des évacuations et des déplacements de populations, conséquences économiques et psychosociales) pour construire une vision commune et distribuer les prises de décision au niveau national, individuel et local.

À l'évidence, un besoin grandissant de recherches dans ces domaines se fait sentir. De ce fait, les articles traitant de la préparation et de la gestion des accidents et des phases post-accidentelles, ainsi que leurs conséquences sont évidemment les bienvenus dans Radioprotection. 


\section{The challenges of crises}

The COVID-19 pandemic currently overwhelming the whole world raises major public health challenges for the emergency phase (with confinement) and the recovery phase (with lifting the confinement). At a first look, there are numerous similarities between the COVID-19 crisis and a nuclear/radiological accident.

In the case of COVID-19 one can observe significant differences in the management of the crisis between the different countries of the world. The impact of the pandemic varies tremendously from one country to another, and it is not completely certain that these differences of management are the cause. Experience feedback will tell us more precisely in some weeks/months. One can also observe the scientific debates, bearing strong and often contradictory opinions, which do not make it possible to clarify the situation. This is entirely due to the positioning of the experts in the debate, a question widely debated after the Fukushima accident.

Consequently, this COVID-19 pandemic crisis is a sign of challenge for us scientists and specialists in all domains dealing with radiological protection. Are we really ready for a nuclear/radiological event of a large size? Will we have a stock of basic equipment needed by the main actors and the population, e.g., electronic dosimeters, to properly manage the emergency phase and radiation counters and spectrometers for the recovery phase? Do we have robust decision-making processes to cope with the acute and the post-accident situations, their radiologic, health, economic and social consequences?

However, there is a major difference with the COVID-19 crisis: preparedness to a nuclear/radiological accident is active in most of concerned countries and strongly based on the experience gained with the management of the Chernobyl and Fukushima nuclear accidents, especially with numerous European research projects. In fact, nuclear/radiological emergency preparedness and response have been for quite a long time a subject of research and indeed an editorial line of Radioprotection.

In this issue, we publish two articles on preparedness. The first article from Croüail et al. is entitled "Analysis of the modalities of return of populations to the contaminated territories following the accident at the Fukushima power plant" (Croüail et al., 2020). This analysis reveals the complexity of the situation in a context of high uncertainty and also emphasizes the need for decisionmakers and decision-helpers (e.g., radiological protection and medical experts) to take into account and respect the different choices made or envisaged by the impacted communities for whom radiological issues are only one face of the problem.

The second article from Maître et al. is entitled "The involvement processes of stakeholders in the management of postaccident situations - which lessons for preparedness?" (Maître et al., 2020). This paper synthesizes the recommendations resulting from six European research projects over a period of 6 years (2013-2019) and highlights the importance of preparedness by engaging as early as possible dialogues with stakeholders in the areas potentially affected by a nuclear accident.

Furthermore, Radioprotection is pleased to currently publish two special issues dedicated to the management of nuclear crisis with a series of articles presenting the last achievements of the European research projects CONFIDENCE and ENGAGE. The CONFIDENCE Project performs research focused on uncertainties in the area of emergency management and long-term rehabilitation. It concentrates on the early and transition phases of an emergency, but considers also longer-term decisions taken during these phases, with specific emphasis on social, ethical and communication aspects (Raskob et al., 2020). The ENGAGE project seeks to identify and address key difficulties and opportunities for stakeholder engagement in the management of postaccident exposures to ionizing radiation as well as the development of the radiological protection culture (also including medical and indoor radon exposures) (Turcanu and Duranova, 2020; Turcanu et al., 2020).

In conclusion, the challenges of crises deal essentially on how the society (decision makers, stakeholders and population) can share the evaluation of the different risks (health consequences of radiological exposures, public health consequences of evacuation and displacement of the population, economic and psycho-social consequences) to build up a common vision and distribute the decision making at the national, individual and local levels.

Obviously, more research is needed in these domains and Radioprotection welcomes papers on accidental and post-accidental preparedness and management and their consequences.

\section{Références}

Croüail P, Schneider T, Gariel JC, Tsubokura M, Naito W, Orita M, Takamura N. 2020. Analysis of the modalities of return of populations to the contaminated territories following the accident at the Fukushima power plant. Radioprotection 55, https://doi.org/10.1051/radiopro/ 2020049

Maître M, Schneidre T, Charron S. 2020. Les démarches d'implication des parties prenantes dans la gestion des situations postaccidentelles - Quels enseignements pour la préparation? Radioprotection 55, https://doi.org/10.1051/radiopro/2020051.

Raskob W, Beresford NA, Duranova T, Korsakissok I, Mathieu A, Montero M, Müller T, Turcanu C, Woda C. 2020. CONFIDENCE: project description and main results. Radioprotection 55(HS1): S7-S15.

Turcanu C, Duranova T. 2020. Editorial: The main results of the European ENGAGE project. Radioprotection 55(HS2): S209-S210.

Turcanu C, Van Oudheusden M, Abelshausen B, Schieber C, SchneiderT, Zeleznik N, Geysmans R, Duranova T, Perko T, Pölzl-Viol C. 2020. Stakeholder engagement in radiological protection: Developing theory, practice and guidelines. Radioprotection 55(HS2): S211-S218.

M. Bourguignon

Rédacteur en chef 